\title{
Effect of Intravenous Amino Acids on Protein Metabolism of Preterm Infants during the First Three Days of Life
}

\author{
AUDELIO RIVERA, JR., EDWARD F. BELL, AND DENNIS M. BIER \\ Departments of Pediatrics, University of Iowa. Iowa City, Iowa 52242 and Washington University: \\ St. Louis, Missouri 63110
}

\begin{abstract}
Twenty-three preterm infants with respiratory distress syndrome (mean birth weight $1.07 \mathrm{~kg}$, SD $0.24 \mathrm{~kg}$ ) were randomly assigned to receive glucose alone or glucose with amino acids $\left(1.5 \mathrm{~g} \cdot \mathrm{kg}^{-1} \cdot \mathrm{d}^{-1}\right)$ i.v. beginning on the 1 st $d$ of life. Blood ammonia and serum urea, $\mathrm{CO}_{2}$ content, sodium, potassium, chloride, and ionized calcium concentrations were normal and did not differ between treatment groups. Nitrogen balance was significantly greater in the group that received amino acids [ 88 (SD 54) versus -135 (SD 45) $\mathrm{mg} \cdot \mathrm{kg}^{-1} \cdot \mathrm{d}^{-1} \mathrm{l}$. In 12 infants (seven, glucose-only; five, glucose and amino acids), leucine kinetic studies were also performed on the 3 rd d of life. These 12 infants received a 4-h primed constant infusion of $L-\left[1-{ }^{13} \mathrm{C}\right]$ leucine. Blood and breath were collected and analyzed for $\left[1-{ }^{13} \mathrm{C}\right]$ ketoisocaproate and ${ }^{13} \mathrm{CO}_{2}$, respectively. Leucine turnover and oxidation were calculated. Both leucine turnover and oxidation were significantly higher in the group receiving amino acids than in the glucose-only group [241 (SD 38) versus 164 (SD 25) $\mu \mathrm{mol} \cdot \mathrm{kg}^{-1} \cdot \mathrm{h}^{-1}$ and 71 (SD 22) versus 40 (SD 17) $\mu \mathrm{mol} \cdot \mathrm{kg}^{-1} \cdot \mathrm{h}^{-1}$, respectively|. In addition, the calculated rate of protein synthesis was higher in the group receiving amino acids $[6.9$ (SD 1.1) versus 5.0 (SD 1.2) $\left.\mathrm{g} \cdot \mathrm{kg}^{-1} \cdot \mathrm{d}^{-1}\right]$. These data indicate that the i.v. administration of amino acids $\left(1.5 \mathrm{~g} \cdot \mathrm{kg}^{-1} \cdot \mathrm{d}^{-1}\right)$ to ill preterm infants beginning on the 1 st $\mathrm{d}$ of life improves wholebody protein balance as a result of increased protein synthesis. (Pediatr Res 33: 106-111, 1993)
\end{abstract}

\section{Abbreviations}

KIC, ketoisocaproate

Recent advances in the treatment of respiratory distress syndrome have dramatically improved the survival of very low birth weight infants, necessitating improvements in early nutritional support given their limited metabolic reserves (1). In the past, the unstable clinical condition and apparently immature metabolic pathways of the newly born preterm infant resulted in the reluctance of physicians to administer i.v. amino acids during the 1 st wk of life. However, the i.v. infusion of amino acids beginning on the $1 \mathrm{st} d$ of life may limit the endogenous nitrogen losses occurring during the $1 \mathrm{st}$ wk and stimulate a greater intake of energy (2).

Data on the safety and efficacy of intravenously infusing amino

Received September 20.1991: accepted September 2, 1992.

Correspondence and reprint requests: Edward F. Bell. M.D., Department of Pediatrics, University of Iowa, Iowa City, IA 52242.

Supported by grants from the National Institutes of Health (HD07578. HD16974, HD20805, and RR00954), Abbott Laboratories, and Gerber Companies Foundation. Dr. Rivera was a fellow supported by NIH Training Grant HD07287. acids in low birth weight infants during the first $3 \mathrm{~d}$ of life are limited $(2,3)$. Utilization of intravenously infused amino acids has been studied in older and more stable infants by nitrogen balance $(4,5)$. However, interpretation of data obtained by the nitrogen balance technique is limited by errors inherent to the method (6).

In vivo kinetics of individual amino acids have been studied to understand the dynamics of protein metabolism (7-9). Leucine, an essential amino acid catabolized mainly in muscle, the body's major protein store, is uniquely suited as a representative amino acid whose kinetics appear to reflect those of whole-body protein turnover, breakdown, and synthesis (8).

Thus, to provide information on the safety and efficacy of i.v. administration of crystalline amino acids to low birth weight infants during the first $3 \mathrm{~d}$ of life, we determined leucine kinetics, nitrogen balance, and various other biochemical indices in these infants.

\section{MATERIALS AND METHODS}

Twenty-three preterm infants (Table 1) with respiratory distress syndrome who were less than $24 \mathrm{~h}$ old and required mechanically assisted ventilation and indwelling arterial catheters were enrolled into a controlled trial comparing parenteral glucose versus glucose plus amino acids during the first $3 \mathrm{~d}$ of life. The birth weights of all infants were appropriate for gestational age as calculated from the Ist $\mathrm{d}$ of the mother's last menstrual period or, when dates were uncertain, by the method of Ballard et al. (10). The study protocol was reviewed and approved by the University of Iowa Committee on Research Involving Human Subjects, and written consent was obtained for each subject from one or both parents.

Patients were assigned by envelope randomization to receive a solution containing glucose alone or glucose and amino acids $\left(1.5 \mathrm{~g} \cdot \mathrm{kg}^{-1} \cdot \mathrm{d}^{-1}\right.$, Aminosyn PF, Abbott Laboratories, North Chicago, IL) i.v. within $24 \mathrm{~h}$ of birth; infusion of the assigned solution was therefore begun on $\mathrm{d} 1$ of life. The amino acid solution used did not contain premixed cysteine because of poor long-term solubility. A cysteine hydrochloride additive (Cysteine Hydrochloride Injection, Abbott Laboratories) is available for use with this solution. This cysteine additive was omitted inadvertently from the nutrient solutions administered to the first four infants assigned to receive glucose and amino acids. The subsequent seven patients received the amino acid solution plus the cysteine additive $(0.5 \mathrm{~g}$ cysteine hydrochloride monohydrate $/ 12.5 \mathrm{~g}$ of other amino acids).

No infant received enteral feedings or parenteral lipid emulsion. The amino acid infusions were started at a mean age of 15 h (SD 3). Nutrient solutions were infused i.v. with the use of mechanical pumps. Thermal support was provided with radiant warmers. Weight was determined daily; fluid intake was recorded, and urine volume was measured and recorded. The 
Table 1. Clinical characteristics

\begin{tabular}{lcc}
\hline & \multicolumn{2}{c}{ Group } \\
\cline { 2 - 3 } & Glucose & $\begin{array}{c}\text { Glucose and } \\
\text { amino acids }\end{array}$ \\
\hline No. & 12 & 11 \\
Birth wt $(\mathrm{kg})^{*}$ & $1.09(0.24)$ & $1.05(0.25)$ \\
Gestational age $(\mathrm{wk})^{*}$ & $28.5(1.8)$ & $28.5(1.8)$ \\
Sex (M:F) & $6: 6$ & $3: 8$ \\
\hline
\end{tabular}

* Mean (SD).

intakes of water, glucose, and electrolytes were ordered by the attending physicians and were not dictated by the experimental protocol. Glucose intake was typically adjusted according to chemical estimates (Chemstrip bG. Boehringer Mannheim Diagnostics, Indianapolis, IN) of blood glucose concentration performed at the bedside every 2 to $4 \mathrm{~h}$.

Biochemical indices. Blood for ammonia nitrogen and ionized calcium was obtained on admission to the study and on the 3rd $\mathrm{d}$ of life. Serum sodium, potassium, chloride, carbon dioxide $\left(\mathrm{CO}_{2}\right.$ content), and urea levels were obtained from clinically indicated monitoring data when available. These analyses, including ammonia and ionized calcium, were performed in the hospital clinical chemistry laboratory using standard methods.

$C$-peptide. C-peptide concentrations in urine were determined by RIA, and C-peptide excretion was expressed as $\mathrm{pmol} / \mathrm{mg}$ creatinine $/ 24 \mathrm{~h}$.

Nitrogen balance. In boys, urine was collected directly into $15-$ $\mathrm{mL}$ test tubes, whereas in girls a specially constructed metabolic mattress was used. Immediately after each voiding, urine was transferred to a refrigerated storage vessel which contained 0.5 $\mathrm{mL}$ of $9 \mathrm{~N} \mathrm{HCl}$. At the end of the collection period, the urine was measured in a graduated cylinder and frozen at $-20^{\circ} \mathrm{C}$.

Urine was digested by the micro-Kjeldahl method, and total nitrogen was determined by microdiffusion (11).

Urine was collected between 48 and $72 \mathrm{~h}$ of age. In 15 infants, urine collections were of $24 \mathrm{~h}$ duration. In eight infants, urine collections were of less than $24 \mathrm{~h}(6-17 \mathrm{~h})$ duration for various technical reasons. Even though some infants had urine collections of less than $24 \mathrm{~h}$. collections of 6 to $12 \mathrm{~h}$ have been shown to be accurate estimates of 24 -h collections in parenterally fed infants (12,13).

Nitrogen intake was calculated from the amount of amino acids infused between 48 and $72 \mathrm{~h}$ of life using the weight ratio of nitrogen to amino acids: this ratio was 0.1617 and 0.1595 for the infants receiving the amino acid solution without and with cysteine, respectively. We calculated nitrogen balance as intake minus urinary excretion. Fecal nitrogen losses were assumed to be negligible because most infants did not produce feces during the period of the balance study. In another study (14) of somewhat older preterm infants (aged 2-5 d) who were not fed enterally and who received greater parenteral intakes of amino acids than did our infants, mean fecal excretion of nitrogen was reported to be $12 \mathrm{mg} \cdot \mathrm{kg}^{-1} \cdot \mathrm{d}^{-1}$. Fecal nitrogen excretion by our infants was probably even less.

Letucine metabolism. To assess whole-body amino acid and protein kinetics, a 4-h leucine tracer study was performed between 68 and $76 \mathrm{~h}$ of age while the infant continued to receive the initially assigned glucose or glucose and amino acid solution. We adapted for use in sick preterm infants the method of leucine kinetics as described by Matthews et al. (15). Our subjects were mechanically ventilated via endotracheal tubes and had indwelling arterial catheters and therefore provided ready access to expired air and blood without additional placement of intravascular catheters.

Leucine kinetic studies were conducted in 16 patients. In all 16 studies, an isotopic plateau of $\left[1-{ }^{13} \mathrm{C}\right]$ leucine in plasma was achieved. In four of the initial five patients, enrichments of ${ }^{13} \mathrm{CO}_{2}$ in breath could not be assessed for technical reasons. We report here results of leucine kinetic studies from 12 infants. These 12 infants were given a priming dose of of $\mathrm{L}-\left[1^{13} \mathrm{C}\right]$ leucine $(4.0$ $\mu \mathrm{mol} \cdot \mathrm{kg}^{-1}$ ) at time zero, followed by a continuous i.v. infusion of $\mathrm{L}-\left[1-{ }^{13} \mathrm{C}\right]$ leucine [mean $6.4 \mu \mathrm{mol} \cdot \mathrm{kg}^{-1} \cdot \mathrm{h}^{-1}$ (SD 0.5)] for 240 min using a calibrated syringe pump (model 975. Harvard Apparatus, Inc., Millis, MA). The last seven infants studied also received a priming dose of $\left[{ }^{13} \mathrm{C}\right]$ bicarbonate $\left(0.15 \mathrm{mg} \cdot \mathrm{kg}^{-1}\right)$ in addition to the priming dose of $\mathrm{L}-\left[1-{ }^{1.3} \mathrm{C}\right]$ leucine. $\mathrm{I}-\left[\mathrm{l}-{ }^{13} \mathrm{C}\right] \mathrm{leucine}$ $\left(99.0 \% 1-{ }^{13} \mathrm{C}\right)$ and sodium $\left[{ }^{13} \mathrm{C}\right]$ bicarbonate $\left(99.0 \%{ }^{13} \mathrm{C}\right)$ were obtained from Tracer Technologies (Somerville. MA).

$\mathrm{CO}_{2}$ output was continuously measured before and during the 4-h leucine balance study using a closed-circuit computerized indirect calorimeter (MGM/jr. Utah Medical Products, Midvale, UT) (16). Leucine metabolism was determined only in infants without evidence of endotracheal tube leak. Endotracheal tube leak was determined audibly and by measuring the $\mathrm{CO}_{2}$ concentration in the oropharynx. Infants were excluded if the oropharyngeal $\mathrm{CO}_{2}$ concentration exceeded $0.03 \%$.

Blood was obtained from a indwelling arterial catheter and quickly placed into a cold vacuum tube (Vacutainer, Becton Dickinson, Rutherford, NJ) containing dry sodium heparin. The blood was immediately centrifuged and the plasma stored at $-60^{\circ} \mathrm{C}$ for later analysis. Blood samples were obtained before administration of the isotope and also 210 and $240 \mathrm{~min}$ after the beginning of the $\mathrm{L}-\left[1-{ }^{13} \mathrm{C}\right]$ leucine infusion to determine the plateau plasma enrichment of $\left[1-{ }^{13} \mathrm{C}\right]$ leucine and $\left[1-{ }^{13} \mathrm{C}\right] \mathrm{KIC}$. In four infants. blood samples were also obtained at 120 and 180 min to further confirm that $\left[1-{ }^{1.3} \mathrm{C}\right]$ leucine and $\left[1-{ }^{1.3} \mathrm{C}\right] \mathrm{KIC}$ were at plateau values. Samples of expired air downstream from a nonbreathing valve and mixing chamber were collected by vacuum into 20-mL tubes (Venoject. Terumo Medical Corp.. Elkton, MD). $\left[1-{ }^{13} \mathrm{C}\right]$ leucine and $\left[1-{ }^{13} \mathrm{C}\right] \mathrm{KIC}$ in plasma and ${ }^{13} \mathrm{CO}_{2}$ in breath were measured as previously described (17-19). In the first five of the 12 infants for whom leucine kinetic data are reported, expired air was collected before administration of isotope and 120,180,210, and $240 \mathrm{~min}$ after beginning the $1 .-[1$ ${ }^{13} \mathrm{C}$ leucine infusion. To assure that a plateau enrichment of carbon- 13 in breath had been reached by $180 \mathrm{~min}$, a $360-\mathrm{min}$ infusion of $1 .-\left[1-{ }^{13} \mathrm{C}\right]$ leucine was performed in one of these five infants. In this infant, a plateau of carbon-13 in breath was apparent by $180 \mathrm{~min}$ after the start of the $\mathrm{I}-\left[1-{ }^{13} \mathrm{C}\right]$ leucine infusion. In the remaining seven infants, a priming dose of $\left[{ }^{13} \mathrm{C}\right]$ bicarbonate was administered i.v. to more quickly achieve a plateau of carbon- 13 in breath. and samples of breath were collected every $20 \mathrm{~min}$. For the five infants that did not receive bicarbonate priming, the plateau value of carbon-13 in breath $\mathrm{CO}_{2}$ was calculated as the mean of values between 180 and 240 min after beginning $1 .-\left[1-{ }^{13} \mathrm{C}\right]$ leucine infusion. For the other seven infants, those receiving a priming dose of bicarbonate, the plateau value of ${ }^{13} \mathrm{CO}_{2}$ in breath was calculated as the mean of values between 120 and $240 \mathrm{~min}$ after beginning the $1 .-\left[1{ }^{1.3} \mathrm{C}\right]$ leucine infusion.

To estimate more accurately the whole-body turnover rate of leucine, the plasma enrichment of $\left[1-{ }^{13} \mathrm{C}\right] \mathrm{KIC}$ was used as an index of leucine tracer dilution throughout the entire system ( 17. 20).

The model for leucine metabolism used here has been used by previous investigators $(15,21)$. The model generates the mass equation

$$
\mathrm{Q}=\mathrm{S}+\mathrm{O}=\mathrm{B}+\mathrm{I}
$$

where $Q$ is the rate of leucine turnover (or rate of appearance or disappearance): $S$. the rate of leucine incorporation into protein: $O$, the rate of leucine oxidation: $B$, the rate of leucine release from protein; and I, the rate of influx of exogenous leucine-in this case, zero for the infants infused only with glucose, and the rate of nontracer leucine intake in the infants infused with glucose and amino acids.

Whole-body leucine turnover was calculated from the dilution 
of the infused $\mathrm{L}-\left[1-{ }^{13} \mathrm{C}\right]$ leucine at isotopic steady state:

$$
\mathrm{Q}=\mathrm{i} \cdot\left(\frac{\mathrm{E}_{\mathrm{i}}}{\mathrm{E}_{\mathrm{p}}}-1\right)
$$

where $\mathrm{i}$ is the $\mathrm{I}-\left[1-{ }^{1.3} \mathrm{C}\right]$ leucine infusion rate $\left(\mu \mathrm{mol} \cdot \mathrm{kg}^{-1} \cdot \mathrm{h}^{-1}\right) ; \mathrm{E}_{\mathrm{i}}$, the enrichment of the $\mathrm{L}-\left[1-{ }^{13} \mathrm{C}\right]$ leucine infused (atoms $\%$ excess); and $E_{p}$, the $\left[1-{ }^{13} \mathrm{C}\right] \mathrm{KIC}$ enrichment in plasma at isotopic plateau (atoms excess). Plasma KIC enrichment is taken to reflect the dilution of the leucine tracer intracellularly and therefore to represent the appearance rate of unlabeled leucine into the wholebody system $(17,20)$.

The rate of ${ }^{13} \mathrm{CO}_{2}$ excretion $\left(\mathrm{F}^{13} \mathrm{CO}_{2}\right)$ was calculated using the following formula:

$$
\mathrm{F}^{13} \mathrm{CO}_{2}=\frac{\mathrm{FCO}_{2} \cdot \mathrm{ECO}_{2}}{\mathrm{~W} \cdot \mathrm{CF}}
$$

where $\mathrm{FCO}_{2}$ is the $\mathrm{CO}_{2}$ production rate $\left(\mu \mathrm{mol} \cdot \mathrm{h}^{-1}\right) ; \mathrm{ECO}_{2}$, the enrichment of exhaled ${ }^{13} \mathrm{CO}_{2}$ (atom \% excess expressed as a fraction); $\mathrm{W}$, the body weight $(\mathrm{kg})$; and $\mathrm{CF}$, the correction factor that accounts for the percentage of ${ }^{13} \mathrm{CO}_{2}$ temporarily retained by the body. CF was assumed to be 0.98 , the mean value reported by Bresson et al. (22) for parenterally fed infants.

Leucine oxidation $\left(\mathrm{L}_{\mathrm{ox}}\right)$ was then determined from the rate of excretion of ${ }^{13} \mathrm{CO}_{2}$ :

$$
\mathrm{L}_{\mathrm{ox}}=\mathrm{F}^{13} \mathrm{CO}_{2} \cdot\left(\frac{1}{\mathrm{E}_{\mathrm{p}}}-\frac{1}{\mathrm{E}_{\mathrm{i}}}\right) \cdot 100
$$

where $E_{p}$ is the plasma enrichment of $\left[1-{ }^{13} \mathrm{C}\right] \mathrm{KIC}$ (atoms $\%$ excess), because $\mathrm{KIC}$ is the direct precursor source of the carbon atom that is first lost during oxidation, and $\mathrm{E}_{\mathrm{i}}$ is the initial enrichment of $\mathrm{L}-\left[1-{ }^{13} \mathrm{C}\right]$ leucine.

From the leucine indices Q, S, O, and $\mathrm{B}$ in equation 1, estimates of whole-body protein turnover, synthesis, and breakdown in $\mathrm{g}$ protein $\cdot \mathrm{kg}^{-1} \cdot \mathrm{d}^{-1}$ were obtained by multiplying the indices of leucine (in $\mu \mathrm{mol} \cdot \mathrm{kg}^{-1} \cdot \mathrm{h}^{-1}$ ) by the constants $24 \mathrm{~h} / \mathrm{d}$ and $1 \mathrm{~g}$ protein $/ 590 \mu \mathrm{mol}$ leucine. The factor of $590 \mu \mathrm{mol}$ leucine/g protein assumes an average leucine content in protein of $7.8 \%(23,24)$. From these values, we calculated net protein balance as synthesis minus breakdown.

Statistical analysis. Biochemical and energy intake data were analyzed for within-group differences by the two-tailed $t$ test and for differences between groups by one-way analysis of variance. C-peptide data were analyzed by the Wilcoxon rank sum test. Leucine kinetics and nitrogen balance data were analyzed for within-group differences by one-way analysis of variance, and significant differences were determined post hoc by the $t$ test. $p$ values less than 0.05 were considered significant.

\section{RESULTS}

The daily energy intakes for the glucose alone and the glucose and amino acid groups differed significantly on d 2 and 3 (Table 2). Infants infused i.v. with glucose alone had a stable intake of energy over the 3-d study period. However, infants given glucose and amino acids had significantly greater intakes of energy on the 2nd and 3rd d of life; the higher energy intakes on $\mathrm{d} 2$ and 3 were entirely due to higher glucose intakes than on $d 1$. The glucose intake in both groups was not dictated by experimental protocol but was adjusted by the treating physicians based on chemical estimates of blood glucose according to standard nurs-

Table 2. Energy intakes in preterm infants $\left(\mathrm{kcal}^{\mathrm{kg}} \mathrm{kg}^{-1} \cdot \mathrm{d}^{-1}\right) *$

\begin{tabular}{lcccc}
\hline \multicolumn{1}{c}{ Group } & $n$ & $\mathrm{~d} 1$ & $\mathrm{~d} 2$ & $\mathrm{~d} \mathrm{3}$ \\
\hline Glucose & 12 & $29(7)$ & $32(10)$ & $35(12)$ \\
Glucose and amino acids & 11 & $35(8)$ & $50(19) \dagger$ & $54(11) \dagger$ \\
\hline
\end{tabular}

${ }^{*}$ Mean (SD).

$\dagger p<0.05$ as compared with glucose-only group. ery procedure. Therefore, we presume that the higher glucose energy intake on $\mathrm{d} 2$ and 3 in the glucose and amino acid group was required to prevent hypoglycemia.

Plasma ammonia concentrations on the $3 \mathrm{rd} \mathrm{d}$ of life were similar and ranged from 45 to $90 \mu \mathrm{mol} / \mathrm{L}$ and from 46 to 82 $\mu \mathrm{mol} / \mathrm{L}$ for the infants infused i.v. with glucose alone and with glucose and amino acids, respectively (Table 3 ).

Serum urea concentrations were similar on $d 1$ and $d 3$ in infants given glucose alone (Table 3 ). Serum urea concentration increased significantly in the infants infused i.v. with a cysteinefree amino acid solution, from $3.8 \mathrm{mmol} / \mathrm{L}$ (SD 1.6) on $\mathrm{d} 1$ to $7.4 \mathrm{mmol} / \mathrm{L}$ (SD 2.2) on $\mathrm{d}$ 3. The serum urea concentrations for infants infused with a cysteine-containing amino acid solution were similar on d 1 and $3,5.3 \mathrm{mmol} / \mathrm{L}$ (SD 2.1) and 5.3 $\mathrm{mmol} / \mathrm{L}$ (SD 2.8), respectively.

The mean $\mathrm{CO}_{2}$ concentrations were similar between groups (Table 3), as were the ionized calcium, sodium, potassium, and chloride concentrations.

The mean excretion of C-peptide was $17.6 \mathrm{pmol} / \mathrm{mg}$ creatinine $/ 24 \mathrm{~h} \mathrm{(SD} \mathrm{11.8)} \mathrm{and} 30.0 \mathrm{pmol} / \mathrm{mg}$ creatine $/ 24 \mathrm{~h}$ (SD 22.3) for the glucose alone and the glucose and amino acid groups. respectively. This difference was not statistically significant.

The infants that received glucose and amino acids were in positive nitrogen balance (Table 4) and retained a mean of 0.6 $\mathrm{g} \cdot \mathrm{kg}^{-1} \cdot \mathrm{d}^{-1}$ (SD 0.3) of protein (amino acids) (88 mg nitrogen. $\left.\mathrm{kg}^{-1} \cdot \mathrm{d}^{-1}\right)$, whereas the infants infused with glucose alone had a mean loss of $0.8 \mathrm{~g}$ protein $\cdot \mathrm{kg}^{-1} \cdot \mathrm{d}^{-1}$ (SD 0.3) (-135 mg nitrogen . $\left.\mathrm{kg}^{-1} \cdot \mathrm{d}^{-1}\right)$, assuming that nitrogen represents $0.160 \mathrm{~g} / \mathrm{g}$ of protein.

Nitrogen balance in infants infused i.v. with the cysteinecontaining amino acid solution was significantly higher $(115 \mathrm{mg}$. $\mathrm{kg}^{-1} \cdot \mathrm{d}^{-1}, \mathrm{SD}$ 41) than in those infused with the cysteine-free amino acid solution (42 $\left.\mathrm{mg} \cdot \mathrm{kg}^{-1} \cdot \mathrm{d}^{-1}, \mathrm{SD} 42\right)$.

Background (baseline) carbon-13 abundance in expired $\mathrm{CO}_{2}$ was not significantly different betweer the groups; it was -14.12 (SD 0.36) $\delta / \mathrm{mil}$ in the infants receiving glucose alone and -14.82 (SD 0.75) $\delta / \mathrm{mil}$ in the infants receiving both glucose and amino acids. The plateau enrichments of plasma $\left[1-^{13} \mathrm{C}\right] \mathrm{KIC}$ and breath ${ }^{13} \mathrm{CO}_{2}$ and the rates of $\mathrm{L}-\left[1-{ }^{13} \mathrm{C}\right]$ leucine infusion and ${ }^{13} \mathrm{CO}_{2}$ excretion in breath were determined for each infant (Table 5). From these data, leucine turnover and oxidation and percentage of leucine turnover oxidized were calculated (Table 6). The mean $\left[1-^{13} \mathrm{C}\right]$ leucine enrichments 210 and $240 \mathrm{~min}$ after the start of the infusion were 3.55 atom \% excess (SD 0.87) and 3.58 atoms $\%$ excess (SD 0.85), respectively. The mean enrichments of [1$\left.{ }^{13} \mathrm{C}\right] \mathrm{KIC} 210$ and $240 \mathrm{~min}$ after the beginning of the i.v. infusion of $\mathrm{L}-\left[1{ }^{13} \mathrm{C}\right]$ leucine were 3.38 atoms \% excess (SD 1.05) and 3.34 atoms \% excess (SD 0.81), respectively.

Leucine turnover was significantly greater in the infants given glucose and amino acids than in those who received only glucose. The mean rate of leucine oxidation was also significantly greater in the infants infused i.v. with glucose and amino acids than in those infants infused i.v. with glucose alone. The percentage of leucine turnover oxidized was similar in the two groups.

The estimated whole-body protein turnover was significantly greater in the infants infused with both glucose and amino acids $\left(9.8 \mathrm{~g} \cdot \mathrm{kg}^{-1} \cdot \mathrm{d}^{-1}, \mathrm{SD} 1.5\right)$ than in those infused with glucose alone $\left(6.7 \mathrm{~g} \cdot \mathrm{kg}^{-1} \cdot \mathrm{d}^{-1}, \mathrm{SD} 0.9\right)$. Protein synthesis was significantly increased in the infants infused with glucose and amino acids, whereas protein breakdown and net balance were similar (Table 7).

\section{DISCUSSION}

The i.v. infusion of amino acids $\left(1.5 \mathrm{~g} \cdot \mathrm{kg}^{-1} \cdot \mathrm{d}^{-1}\right)$ in sick low birth weight infants during the first $3 \mathrm{~d}$ of life appears to be safe based on the biochemical indices we measured. In addition, we previously (3) found no abnormal elevations of plasma amino acids in preterm infants given this regimen of early amino acid infusion. Low or normal concentrations of all measured plasma amino acids were found despite amino acid supplementation (3). 
Table 3. Biochemical indices*

\begin{tabular}{|c|c|c|c|c|c|c|c|c|}
\hline & \multicolumn{8}{|c|}{ Group } \\
\hline & \multicolumn{4}{|c|}{ Glucose } & \multicolumn{4}{|c|}{ Glucose and amino acids } \\
\hline & $n$ & d 1 & $n$ & d 3 & $n$ & d 1 & $n$ & d 3 \\
\hline Plasma ammonia $(\mu \mathrm{mol} / \mathrm{L})$ & 6 & $65(20)$ & 8 & $65(14)$ & 5 & $83(29)$ & 5 & $59(14)$ \\
\hline Serum urea $(\mathrm{mmol} / \mathrm{L})$ & 12 & $4.6(1.4)$ & 12 & $4.6(1.4)$ & 11 & $5.0(2.1)$ & 11 & $6.1(2.9)$ \\
\hline $\mathrm{CO}_{2}(\mathrm{mmol} / \mathrm{L})$ & 11 & $22(2)$ & 12 & $23(5)$ & 11 & $22(2)$ & 11 & $24(4)$ \\
\hline
\end{tabular}

* Mean (SD).

Table 4. Nitrogen halance data $\left(\mathrm{mg} \cdot \mathrm{kg}^{-1} \cdot d^{-1}\right)$

\begin{tabular}{lcrrc}
\multicolumn{1}{c}{ Group } & $n$ & $\begin{array}{c}\text { Nitrogen } \\
\text { intake* }\end{array}$ & $\begin{array}{c}\text { Urine } \\
\text { nitrogen* }\end{array}$ & $\begin{array}{c}\text { Nitrogen } \\
\text { balance* }\end{array}$ \\
\hline $\begin{array}{l}\text { Glucose } \\
\begin{array}{l}\text { Glucose and amino } \\
\text { acids }\end{array}\end{array}$ & 12 & $0(0)$ & $135(45)$ & $-135(45)$ \\
& & $250(8)$ & $156(52)$ & $88(54) \dagger$ \\
\end{tabular}

* Mean (SD).

$+p<0.05$ as compared with glucose-only group.

The lack of elevated plasma amino acid concentrations lends further support to the safety of amino acids administered i.v. beginning on the 1 st $d$ of life.

It is well known that sufficient nonprotein energy must be consumed to efficiently utilize ingested protein. Although not as well recognized, amino acids modify energy intake by releasing insulin $(25,26)$, which creates a need for more exogenous glucose energy to prevent hypoglycemia. The early infusion of amino acids in preterm infants appears to have altered glucose metabolism, increasing their need for glucose. Previous investigators $(26,27)$ have shown that preterm infants infused i.v. with amino acids have greater serum insulin concentrations than those infused with glucose alone. Although not statistically significant, urinary C-peptide excretion (a marker for insulin secretion) tended to be greater in our infants receiving glucose and amino acids. Additional work is needed to quantitate the effects of amino acids on insulin secretion in the critically ill low birth weight infant.

The i.v. administration of similar amounts of amino acids ( 1.5 $\left.\mathrm{g} \cdot \mathrm{kg}^{-1} \cdot \mathrm{d}^{-1}\right)$ to ill preterm infants has been shown previously $(4$. 5) to result in positive nitrogen balance despite inadequate energy intake. Our demonstration of positive nitrogen balance in infants infused with amino acids should be interpreted with caution because of the short period of study and the low nonprotein energy intake $(6,28)$. The metabolic fate of the infused amino acids, moreover, cannot be determined on the basis of nitrogen balance.

Infants infused with cysteine-containing amino acid solution retained a significantly greater amount of infused nitrogen than did infants receiving cysteine-free solution. Moreover, the serum concentration of urea nitrogen increased significantly during the 3 -d study period only in the infants who did not receive cysteine. Bodwell (29) has summarized evidence indicating that when proteins of different quality are fed to provide similar nitrogen intakes, animals consuming the protein of lower quality demonstrate higher serum levels of urea nitrogen. Serum concentration of urea nitrogen has been used as an index of the adequacy of the amino acid intake in studies of rats (30) and human adults (31) and infants (32-34) during steady state conditions.

Hepatic cystathionase activity is extremely low in early fetal life and increases slowly as the fetus reaches term (35). Snyderman (36) suggested that cystine may be an essential amino acid for the preterm infant, but her data were not presented in sufficient detail to permit thorough review. Previous studies in parenterally fed infants have failed to demonstrate a significant effect of cysteine on nitrogen balance or growth $(37,38)$. These studies examined larger and older preterm infants than those in our study.

We speculate that, in infants of less than 32 wk gestation, cystathionase is not present in sufficient quantity during the first $3 \mathrm{~d}$ of life to permit adequate conversion of methionine to cysteine. However, sufficient activity may appear with increased gestational age or postnatal age so that exogenous cysteine is no longer essential (39).

Leucine turnover and oxidation have been studied in term infants $(40,41)$ with results similar to those in our study of preterm infants infused with glucose alone for $3 \mathrm{~d}$. Frazer and Bier (40) studied four term infants at 4 to $8 \mathrm{~h}$ of age, whose mean rate of leucine turnover was $151 \mu \mathrm{mol} \cdot \mathrm{kg}^{-1} \cdot \mathrm{h}^{-1}$ (SD 28). Denne and Kalhan (41) measured leucine kinetics in 12 term infants

Table 5. Isotopic enrichment of plasma KIC and expired $\mathrm{CO}_{2}$ at platean*

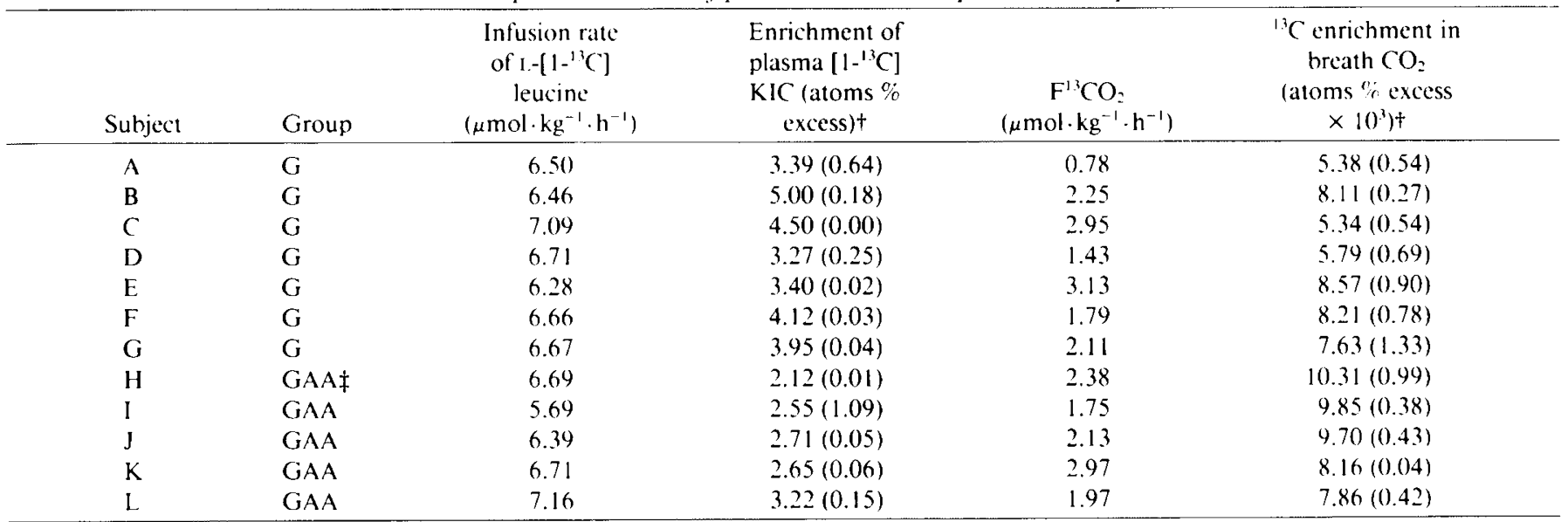

* G, glucose-only group: GAA, glucose and amino acid group: $\mathrm{F}^{13} \mathrm{CO}_{2}$, rate of ${ }^{13} \mathrm{CO}_{2}$ excretion in breath.

+ Mean of two to four samples for plasma and two to eight samples for breath (SD).

$\ddagger$ Subject $\mathrm{H}$ did not receive cysteine hydrochloride additive: the other four GAA subjects did. 
Table 6. Lencine metabolism $\left(\mu \mathrm{mol} \cdot \mathrm{kg}^{-1} \cdot \mathrm{h}^{-1}\right)^{*}$

Leucine

turnover oxidized

\begin{tabular}{|c|c|c|c|c|}
\hline Group & $n$ & Turnover & Oxidation & $(\%)$ \\
\hline Cilucose & 7 & $164(25)$ & $40(17)$ & $25(10)$ \\
\hline $\begin{array}{l}\text { Cilucose and amino } \\
\text { acids }\end{array}$ & 5 & $241(38) \dagger$ & $71(22) \dagger$ & $29(7)$ \\
\hline
\end{tabular}

* Mean (SD).

$+p<0.05$ as compared with glucose-only group.

Table 7. Effect of amino acid supplementation on protein slinthesis, breakdown. and net tissue gain $\left(\mathrm{g} \cdot \mathrm{kg}^{-1} \cdot \mathrm{d}^{-1}\right)^{*}$

\begin{tabular}{lllcc}
\multicolumn{1}{c}{ Group } & $n$ & Synthesis & Breakdown & $\begin{array}{c}\text { Synthesis minus } \\
\text { breakdown }\end{array}$ \\
\hline $\begin{array}{l}\text { Cilucose } \\
\begin{array}{l}\text { Glucose and amino } \\
\text { acids }\end{array}\end{array}$ & 5 & $5.0(1.2)$ & $6.7(1.0)$ & $-1.6(0.7)$ \\
\hline
\end{tabular}

* Mean (SD).

$+p<0.05$ as compared with glucose-only group.

between 1 and $3 \mathrm{~d}$ of age who were fasted for 6 to $9 \mathrm{~h}$. Mean leucine turnover was $164 \mu \mathrm{mol} \cdot \mathrm{kg}^{-1} \cdot \mathrm{h}^{-1}$ (SD 28) in their 12 term infants, the same as the mean leucine turnover value in our seven preterm infants infused with glucose alone for $3 \mathrm{~d}, 164$ $\mu \mathrm{mol} \cdot \mathrm{kg}^{-1} \cdot \mathrm{h}^{-1}$ (SD 25). Leucine oxidation in the term infants studied by Denne and Kalhan (41) was $34 \mu \mathrm{mol} \cdot \mathrm{kg}^{-1} \cdot \mathrm{h}^{-1}$ (SD 11), as compared with $40 \mu \mathrm{mol} \cdot \mathrm{kg}^{-1} \cdot \mathrm{h}^{-1}$ (SD 21) in our preterm infants receiving glucose alone.

Increased rates of leucine turnover have been shown with enterally fed preterm infants in both the fed and postabsorptive states (42, 43). de Benoist ' $t$ al. (42) studied leucine kinetics in seven continuously fed preterm infants weighing a mean of 1.73 $\mathrm{kg}$ with a mean age of $22 \mathrm{~d}$. Leucine turnover averaged 333 $\mu \mathrm{mol} \cdot \mathrm{kg}^{-1} \cdot \mathrm{h}^{-1}$ (SD 44): the mean rate of leucine oxidation was $42 \mu \mathrm{mol} \cdot \mathrm{kg}^{-1} \cdot \mathrm{h}^{-1}$ (SD 17). Denne (43) studied leucine kinetics in seven postabsorptive preterm infants (mean $7.7 \mathrm{~d}$ of age): their leucine turnover and oxidation rates were $233 \mu \mathrm{mol} \cdot \mathrm{kg}^{-1} \cdot \mathrm{h}^{-1}$ (SD 58) and $28 \mu \mathrm{mol} \cdot \mathrm{kg}^{-1} \cdot \mathrm{h}^{-1}$, respectively. Leucine turnover in our five preterm infants receiving amino acids i.v., $241 \mu \mathrm{mol}$. $\mathrm{kg}^{-1} \cdot \mathrm{h}^{-1}$ (SD 38), was similar to that in postabsorptive preterm infants (43) but lower than in fed infants (42). The rate of leucine oxidation in our infants receiving amino acids, $71 \mu \mathrm{mol} \cdot \mathrm{kg}^{-1}$. $\mathrm{h}^{-1}$ (SD 27), was higher than the rate of oxidation found in the infants studied by de Benoist el al. (42) and Denne (43). These rates of leucine oxidation most likely reflect the overall clinical and nutritional status of these infants. An alternative explanation might be that parenterally delivered amino acids are disposed of more rapidly than are those fed enterally.

Our infants infused i.v. with glucose alone had protein turnover rates $\left(6.7 \mathrm{~g} \cdot \mathrm{kg}^{-1} \cdot \mathrm{d}^{-1}\right)$ that were similar to those of the term infants studied by Frazer and Bier (40) and Denne and Kalhan (41) $\left(6.1 \mathrm{~g} \cdot \mathrm{kg}^{-1} \cdot \mathrm{d}^{-1}\right.$ and $6.7 \mathrm{~g} \cdot \mathrm{kg}^{-1} \cdot \mathrm{d}^{-1}$, respectively). This similarity between term and preterm infants contrasts with the data of Nissim el al. (44), who found higher protein turnover rates in younger and less mature infants. Our results suggest that protein turnover in infants is influenced by energy and nutrient intake. Despite the period of negative energy balance in our glucosealone group, protein turnover was high as compared with the fasted adult (15) and was consistent with the findings of Denne and Kalhan (41).

The rate of protein synthesis was higher in the infants infused i.v. with glucose and amino acids than in the glucose-alone group. Further, the increased rate of protein synthesis coupled with an unchanged rate of protein breakdown resulted in improved protein balance in the infants administered glucose and amino acids. However, the increased rate of protein synthesis seen in the infants infused with glucose and amino acids cannot be attributed solely to the intake of amino acids but may reflect the interactions of increased insulin secretion (45) and glucose intake (46) or the difference in energy intake on $\mathrm{d} 2$ and 3 (Table 2).

Whole-body protein balance was assessed with leucine kinetics. Infants infused with glucose alone had a mean loss of $1.6 \mathrm{~g} \cdot \mathrm{kg}^{-1}$. $\mathrm{d}^{-1}$ of endogenous body protein, representing a $5 \%$ loss of total body protein during the $3-d$ study period assuming the same daily loss and assuming that the protein content of a $1-\mathrm{kg}$ infant is $94 \mathrm{~g} \mathrm{(47).} \mathrm{Alternatively,} \mathrm{in} \mathrm{infants} \mathrm{infused} \mathrm{with} \mathrm{glucose} \mathrm{and}$ amino acids $\left(1.5 \mathrm{~g} \cdot \mathrm{kg}^{-1} \cdot \mathrm{d}^{-1}\right)$, net protein balance was $-0.5 \mathrm{~g}$. $\mathrm{kg}^{-1} \cdot \mathrm{d}^{-1}$. which represents a $2 \%$ loss of total body protein during the 3 -d study period. These estimates differ from the data obtained by the nitrogen balance technique. Using urinary nitrogen excretion to estimate protein balance, a $3 \%$ loss and a $2 \%$ gain of total body protein would have been inferred in our infants infused i.v. with glucose alone and with glucose and amino acids. respectively. This discrepancy is probably due, at least in part, to the tendency of the nitrogen balance technique to overestimate nitrogen retention $(6.28)$.

The effects of infused amino acids on protein synthesis and breakdown found in our study using $\mathrm{L}-\left[1-{ }^{13} \mathrm{C}\right]$ leucine (Table 7) are very similar to the results of a similar study recently reported by van Lingen $e t$ al. (48) using $\left[{ }^{15} \mathrm{~N}\right]$ glycine.

In summary, early amino acid administration $\left(1.5 \mathrm{~g} \cdot \mathrm{kg}^{-1} \cdot \mathrm{d}^{-1}\right)$ appears to be biochemically safe. An increased rate of wholebody protein synthesis coupled with an unchanged rate of protein breakdown is seen with the administration of amino acids. resulting in improved protein balance. The early administration of amino acids was associated with a greater intake of energy. perhaps as a result of increased insulin secretion. Additional study of the safety and efficacy of infused amino acids in the first days of life is warranted.

Acknowledgment. The authors thank Philip G. Gruppuso for performing the C-peptide assays.

\section{REFERENCES}

1. Bell EF, Oh W 1988 Nutritional support. In: Goldsmith JP. Karotkin EH (eds) Assisted Ventilation of the Neonate, 2nd Ed. WB Saunders Co. Philadelphia. pp 307-327

2. Saini J, Macmahon P. Morgan JB, Kovar IZ 1989 Early parenteral feeding of amino acids. Arch Dis Child 64:1362-1366

3. Rivera Jr A, Bell EF, Stegink LD. Ziegler EE 1989 Plasma amino acid profiles during the first three days of life in infants with respiratory distress syndrome: effect of parenteral amino acid supplementation. J Pediatr 1 15:465-468

4. Anderson TL, Muttart CR, Bieber MA, Nicholson JF, Heird WC 1979 A controlled trial of glucose versus glucose and amino acids in premature infants. J Pediatr 94:947-951

5. Rubecz I, Mestyán J, Varga P, Klujber L 1981 Energy metabolism, substrate utilization, and nitrogen balance in parenterally fed postoperative neonates and infants. J Pediatr 98:42-46

6. Fomon SJ, Owen GM 1962 Comment on metabolic balance studies as a method of estimating body composition of infants with special consideration of nitrogen balance studies. Pediatrics 29:495-498

7. James WPT, Garlick PJ. Sender PM. Wateriow JC 1975 Studies of amino acid protein metabolism in normal man with $\mathrm{I}-\left[\mathrm{U}-{ }^{14} \mathrm{C}\right]$ tyrosine. Clin Sci Mol Med 50:525-532

8. Golden MHN. Waterlow JC 1977 Total protein synthesis in elderly people: a comparison of results with $\left[{ }^{15} \mathrm{~N}\right]$ glycine and $\left[{ }^{14} \mathrm{C}\right]$ leucine. Clin Sci Mol Med 53:277-288

9. Fern EB, Garlick PJ, McNurlan MA, Waterlow JC 1981 The excretion of isotope in urea and ammonia for estimating protein turnover in man with $\left[{ }^{15} \mathrm{~N}\right] \mathrm{glycine}$. Clin Sci 61:217-228

10. Ballard JL. Novak KK. Driver M 1974 A simplified score for assessment of fetal maturation of newly born infants. J Pediatr 95:769-774

11. Conway EJ. O’Malley E 1942 Microdiffusion methods. Ammonia and urea using buffered absorbents (revised method for ranges greater than $10 \mu \mathrm{g} \mathrm{N}$ ). Biochem J 36:655-660

12. Lopez AM, Wolfdorf J. Raszynski A. Contijoch-Serrano V 1986 Estimation of nitrogen balance based on a 6 -hour collection in infants. J Parenter Enteral Nutr 10:517-518

13. Pineault M. Maag U. Chessex P 1990 Reliability of the twenty-four-hour nitrogen balance in parenterally fed newborn infants. J Parenter Enteral Nutr 14:53-55

14. Anderson GH. Bryan H. Jeejeebhoy KN. Corey P 1977 Dose response relationships between amino acid intake and blood levels in newborn infants. Am J Clin Nutr 30:1110-1121 


\section{PROTEIN METABOLISM IN PRETERM INFANTS}

15. Matthews DE. Motil KJ. Rohrbaugh DK. Burke JF, Young VR. Bier DM 1980 Measurement of leucine metabolism in man from a primed. continuous infusion of $1-\left[1-{ }^{13} \mathrm{C}\right] \mathrm{leucine}$. Am J Physiol 238:E473-E479

16. Mavfield SR 1991 Technical and clinical testing of a computerized indirect calorimeter for use in mechanically ventilated neonates. Am J Clin Nutr $54: 30-34$

17. Matthews DE. Schwarz HP. Yang RD. Motil KJ. Young VR, Bier DM 1982 Relationship of plasma leucine and $\alpha$-ketoisocaproate during a $1 .-\left[1-{ }^{13} \mathrm{C}\right]$ leucine infusion in man: a method for measuring human intracellular leucine tracer enrichment. Metabolism 31:1105-1112

18. Adams RF 1974 Determination of amino acid profiles in biological samples by gas chromatography. J Chromatogr 57:189-212

19. Matthews DE. Ben Galim E. Bier DM 1979 Determination of stable isotopic enrichment in individual plasma amino acids by chemical ionization mass spectrometry. Anal Chem 51:80-84

20. Bier DM 1989 Intrinsically difficult problems: the kinetics of body proteins and amino acids in man. Diabetes Metab Rev 5:111-132

21. O'Keefe SJD. Sender PM. James WPT 1974 "Catabolic" loss of body protein in response to surgery. Lancet 2:1035-1038

22. Bresson JL. Mariotti A. Narcy P. Ricour C. Sachs C. Rey J 1990 Recovery of $\left[{ }^{13} \mathrm{C}\right]$-bicarbonate as respiratory " $\mathrm{CO}_{2}$ in parenterally fed infants. Eur J Clin Nutr 44:3-9

23. Orr ML. Watt BK 1968 Amino Acid Content of Foods. U.S. Department of Agriculture, Washington, $D C$

24. Block RJ. Weiss KW 1956 Amino Acid Handbook: Methods and Results of Protein Analysis. Thomas, Springfield. IL

25. Floyd JC. Fajans SS. Conn JW. Knoff RF. Rull J 1966 Stimulation of insulin secretion by amino acids. J Clin Invest 45:1487-1502

26. Grasso S. Saporito N. Messina H. Retiano G 1968 Serum-insulin response to glucose and amino acids in the premature infant. Lancet 2:755-757

27. Andronikou S. Hanning I 1987 Parenteral nutrition effect on serum insulin in the preterm infant. Pediatrics 80:693-697

28. Forbes GB 1973 Another source of error in the metabolic balance method Nutr Rev 31:297-300

29. Bodwell CE 1977 Biochemical indices in humans. In: Bodwell CE (ed) Evalu ation of Proteins for Humans. AVI Publishing. Westport. CT. pp 119-148

30. Eggum BO 1970 Blood urea measurement as a technique for assessing protein quality. Br J Nutr 24:983-988

31. Taylor YSM. Scrimshaw NS. Young VR 1974 The relationship between serum urea levels and dietary nitrogen utilization in young men. Br J Nutr 32:407411

32. Fomon SJ, Ziegler EE. Filer Jr LJ, Velson SE, Edwards BB 1979 Methionine fortification of a soy protein formula fed to infants. Am J Clin Nutr 32:24602471
33. Fomon SJ. Ziegler EE. Nelson SE, Edwards BB 1986 Requirement for sulfurcontaining amino acids in infancy. J Nutr 116:1405-1422

34. Kashyap S. Forsyth M. Zucker C. Ramakrishnan R. Dell RB. Heird WC 1986 Effects of varying protein and energy intakes on growth and metabolic response in low birth weight infants. J Pediatr 108:955-963

35. Sturman JA. Gaull G. Räihä NCR 1970 Absence of cystathionase in human fetal liver: is cystine essential? Science 169:74-76

36. Snvderman SE 1971 The protein and amino acid requirements of the premature infant. In: Jonxis JHP. Visser HKA. Troelstra JA (eds) Metabolic Processes in the Foetus and Newborn Infant. Stenfert HE. Knoese NV. Leiden. The Netherlands, pp 128-141

37. Zlotkin SH. Bryan MH. Anderson GH 1981 Cysteine supplementation to cystine-free intravenous feeding regimens in newborn infants. Am J Clin Nutr 34:914-923

38. Malloy MH. Rassin DK. Richardson CJ 1984 Total parenteral nutrition in sick preterm infants: effects of cysteine supplementation with nitrogen intakes of 240 and $400 \mathrm{mg} / \mathrm{kg} /$ day. J Pediatr Gastroenterol Nutr 3:239-244

39. Zlotkin SH. Anderson GH 1982 The development of cystathionase activity during the first year of life. Pediatr Res 16:65-68

40. Frazer TE, Bier DM 1980 Essential amino acid turnover in the human newborn. Pediatr Res 14:571(abstr)

41. Denne SC. Kalhan SC 1987 Leucine metabolism in human newborns. Am J Physiol 253:E608-E615

42. de Benoist B. Abduirazzak Y. Brooke OG Halliday D. Millward DJ 1984 The measurement of whole body protein turnover in the preterm infant with intragastric infusion of $1,-\left[1-{ }^{1} \mathrm{C}\right]$ leucine and sampling of the urinary leucine pool. Clin Sci 66:155-164

43. Denne SC 1990 Leucine and protein metabolism in postabsorptive premature newborns. Pediatr Res 27:282A(abstr)

44. Nissim I, Yudkoff M. Pereira G. Segal S 1983 Effects of conceptual age and dietary intake on protein metabolism in premature infants. J Pediatr Gastroenterol Nutr 2:507-516

45. Fukagawa NK. Minaker KL. Rowe JW. Goodman MN. Matthews DE. Bier DM. Young VR 1985 Insulin-mediated reduction of whole body protein breakdown. Dose-response effects on leucine metabolism in postabsorptive men. J Clin Invest 76:2306-2311

46. Sim AJW. Wolfe BM. Young VR. Clarke D 1979 Glucose promotes wholebody protein synthesis from infused amino acids in fasting man. Lancet $1: 78-72$

47. Ziegler EE. O’Donnell AM. Nelson SE. Fomon SJ 1976 Body composition of the reference fetus. Growth 40:329-341

48. van Lingen RA, van Goudoever JB, Luijendijk IHT, Wattimena JLD, Sauer PJJ 1992 Effects of early amino acid administration during total parenteral nutrition on protein metabolism in pre-term infants. Clin Sci 82:199-203 